\title{
Integrated Grazing and Prescribed Fire Restoration Strategies in a Mesquite Savanna: I. Vegetation Responses
}

\author{
W. R. Teague, ${ }^{1}$ S. L. Dowhower, ${ }^{2}$ R. J. Ansley, ${ }^{1}$ W. E. Pinchak, ${ }^{1}$ and J. A. Waggoner ${ }^{3}$ \\ Authors are ${ }^{1}$ Professors, ${ }^{2}$ Senior Research Associate, and ${ }^{3}$ Research Associate, Texas AgriLife Research, Texas A $\mathrm{W}$ University System, PO Box 1658, \\ Vernon, TX 76385-1658, USA.
}

\begin{abstract}
This study evaluated the efficacy of prescribed fire applied within landscape-scale rotational grazing treatments to reduce mesquite (Prosopis glandulosa Torr.) encroachment and restore herbaceous productivity and cover. One-herd, multiple-paddock rotational grazing was used to accumulate herbaceous fine fuel for fires via prefire deferment and to provide periodic postfire deferment for grass recovery. Treatments were an unburned continuous-grazed control, a four-paddock-1 herd system with fire (4:1F), and an eight-paddock-1 herd system with fire (8:1F), with two replicates per treatment (1294-2130 ha per replicate). The management plan was to burn $25 \%$ of each system (one paddock in the 4:1F; two paddocks in the $8: 1 \mathrm{~F}$ treatments) and defer grazing during all or portions of the 9 mo (May to January) prior to burning. Deferral was "internalized" by grazing on the remaining $75 \%$ of each treatment without reducing stocking rate determined for the entire system. Mesquite cover increased on clay-loam soils from $22 \%$ to $40 \%$ in unburned paddocks over $7 \mathrm{yr}$ (1995-2001). This increase, coupled with extended drought, reduced fine fuel amounts for fire and limited the number and intensity of fires that were applied. It was possible to burn one paddock in the 8:1F treatment ( $12.5 \%$ of total area), but not in the $4: 1 \mathrm{~F}$ treatment $(25 \%$ of total area) during drought. Fires reduced mesquite and cactus (Opuntia spp.) cover by $25-79 \%$ and $24-56 \%$, respectively, but cover of these species increased to prefire levels within 6 yr. All fires reduced $(P \leq 0.05)$ total herbaceous biomass for $1 \mathrm{yr}$ postfire. The 8:1F treatment increased $(P \leq 0.05)$ grass biomass on loamy-bottom soils and reduced $(P \leq 0.05)$ bare ground on clay-loam and loamy-bottom soils in unburned paddocks compared to the unburned continuously grazed control. The $8: 1 \mathrm{~F}$ treatment, through internalized grazing deferment, facilitated the application of fire to reduce woody cover during extended drought without degrading the herbaceous understory.
\end{abstract}

\section{Resumen}

Este estudio evaluó el beneficio de las quemas prescritas utilizadas a nivel de potreros en tratamientos de pastoreo rotacional para reducir la invasión de Mezquite (Prosopis glandulosa Torr.) y rehabilitar la productividad y la cubierta herbácea. Se utilizó un pastoreo rotacional con varios potreros y un solo hato para la acumulación de combustible fino para la quema, por medio del diferimiento antes de la quema y dando períodos de descanso después de la quema para la recuperación de las gramíneas. Los tratamientos fueron, como control, un pastoreo contínuo sin quema, un sistema de 4 potreros- con 1 hato y quema (4:1Q), y un sistema de 8 potreros con un hato y quema (8:1Q), y con dos repeticiones por tratamiento (1294-2130 hectáreas por repetición). El plan de manejo fue quemar el $25 \%$ de cada sistema (1 potrero en el tratamiento 4: 1Q; 2 potreros en el tratamiento 8:1Q), y diferimiento del pastoreo durante o parte de todos los 9 meses (mayo a enero) antes de las quemas. El diferimiento por el pastoreo fue "interno" en el restante $75 \%$ de cada tratamiento sin reducir la capacidad de carga determinada para todo el sistema. La cobertura del mezquite se incrementó en los suelos arcillo-limosos del $22 \%$ a $40 \%$ en los potreros sin quemas durante un periodo de 7 años (1995-2001). Este aumento, junto con la sequía prolongada, redujo la cantidad de combustible fino para el uso del fuego, limitando la intensidad y el número de fuegos que se utilizaron. Durante la sequia fue posible quemar un potrero en el tratamiento 8:1Q (12.5\% del área total), pero no en el tratamiento 4:1Q (25\% del área). El fuego redujo la cobertura tanto del mezquite como de los cactus (Opuntia spp.) $25-79 \%$ y $24-56 \%$ respectivamente, pero la cobertura de estas especies se incrementó a los niveles encontrados antes del uso del fuego en un lapso de 6 años. Todas las quemas redujeron $(P \leq 0.05)$ la biomasa total de las herbáceas por un año después de las quemas. El tratamiento de $8: 1 \mathrm{Q}$ aumentó $(P \leq 0.05)$ la biomasa de las gramíneas en suelos arcillosos en áreas bajas y redujo $(P \leq 0.05)$ el suelo desnudo en suelos arcillo-limosos y suelos arcillosos en áreas bajas en potreros no quemados comparados con el pastoreo continuo sin quema utilizado como control. El tratamiento 8:1Q, a través del diferimiento interno, facilitó la aplicación de las quemas para reducir la cubierta leñosa durante la sequía prolongada sin degradar la cubierta herbácea.

Key Words: brush, cactus, drought, Prosopis glandulosa, ranching systems, rangeland restoration

Funding was provided by the E. Paul and Helen Buck Waggoner Foundation, Inc, the US Department of Agriculture, National Research Initiative Competitive Grants Program Agricultural Systems Grants 94-37211-1172 and 98-35108-6491, the North Texas Brush Control Association (Albany, TX), and Texas AgriLife Research (Hatch project 8179). The W. T. Waggoner Estate (Vernon, TX) provided land area, facilities, management personnel, and cattle for the project. Correspondence: W. R. Teague, Texas AgriLife Research, PO Box 1658, Vernon, TX 76385-1658, USA. Email: r-teague@tamu.edu

Manuscript received 21 July 2008; manuscript accepted 19 December 2009.

\section{INTRODUCTION}

Woody plant abundance has increased in grasslands and savannas worldwide over the past century (Scholes and Archer 1997; Van Auken 2000; Archer et al. 2001; Sankaran et al. 2005). In the southern Great Plains honey mesquite (Prosopis glandulosa Torr.) has invaded many grasslands and savannas 
(McDaniel et al. 1982; Laxson et al. 1997; Asner et al. 2003). Causes of this invasion include reduced fire frequency, livestock overgrazing, increased seed distribution via livestock consumption and fecal deposition, removal of prairie dogs (Cynomys ludovicianus), and increased $\mathrm{CO}_{2}$ levels that possibly favor growth of $\mathrm{C}_{3}$ shrubs over $\mathrm{C}_{4}$ grasses (Blackburn and Tueller 1970; Schlesinger et al. 1990; Polley et al. 1994; Archer 1995; Collins et al. 1998; Kramp et al. 1998; Weltzin et al. 1998). If left unchecked, mesquite encroachment progresses until a closed canopy woodland thicket develops (Laxson et al. 1997; Ansley et al. 2001). This threatens the sustainability of livestock ranching, alters wildlife habitat, biodiversity, and biogeochemistry, and has consequences for land-surfaceatmospheric interactions (Scifres et al. 1988; Archer et al. 2001; Hamilton and Ueckert 2004; Teague et al. 2008a).

Prescribed fire is a less-costly means of reducing mesquite canopy cover compared to mechanical or chemical treatments (Wright and Bailey 1982; Teague et al. 2001). However, for fire to be effective in reducing mesquite cover, grazing must be deferred to accumulate sufficient herbaceous fine fuel (i.e., grass) to carry a fire (Ansley et al. 1998; Ansley and Jacoby 1998). In addition, adequate postfire grazing deferment is important to allow grasses to recover from the fire disturbance (Scifres and Hamilton 1993; Ansley and Taylor 2004). Because fire only suppresses and does not kill mature mesquite, a system must also provide a means for repeated burning to maintain suppression. We hypothesized that one-herd, multiple-paddock rotational grazing systems could accomplish these goals by deferring grazing in paddocks to be burned and limiting grazing in recently burned paddocks until grasses recovered (Teague et al. 1997). Costs of prefire grazing deferral could be "internalized" by burning a small percentage of the system each year and rotationally grazing the entire herd on the remaining portion of the system without reducing the stocking rate predetermined for the entire system. We also hypothesized that older-burned paddocks with reduced mesquite cover would be more productive and would have a greater livestock carrying capacity than unburned paddocks as part of the internalized deferral procedure.

Climate and soils determine the abundance and composition of woody plants and the influence they have on the herbaceous layer in arid and semiarid ecosystems (Walker 1987; Scholes and Archer 1997; Sankaran et al. 2005). The integrated effects of climate, soil type, grazing, and fire on woody plantherbaceous relations is not well understood in rangeland ecosystems and needs further documentation, especially at landscape scales (Andales et al. 2006; Teague et al. 2008a).

Our objective was to evaluate the potential of one-herd, multiple-paddock rotational grazing strategies to facilitate the application of prescribed fire for woody plant suppression through internalized grazing deferment, and simultaneously maintain or improve herbaceous production and cover and livestock (cattle) productivity. Replicated, landscape-scale management units were utilized to assess responses at scales relevant to working ranches in the southern Great Plains (Teague 1996; Teague et al. 1997, 2008c). This paper focuses on woody and herbaceous vegetation responses on different soil types within rotationally grazed and burned systems compared to an unburned continuously grazed control. Companion papers to this study measured fire behavior and landscape-

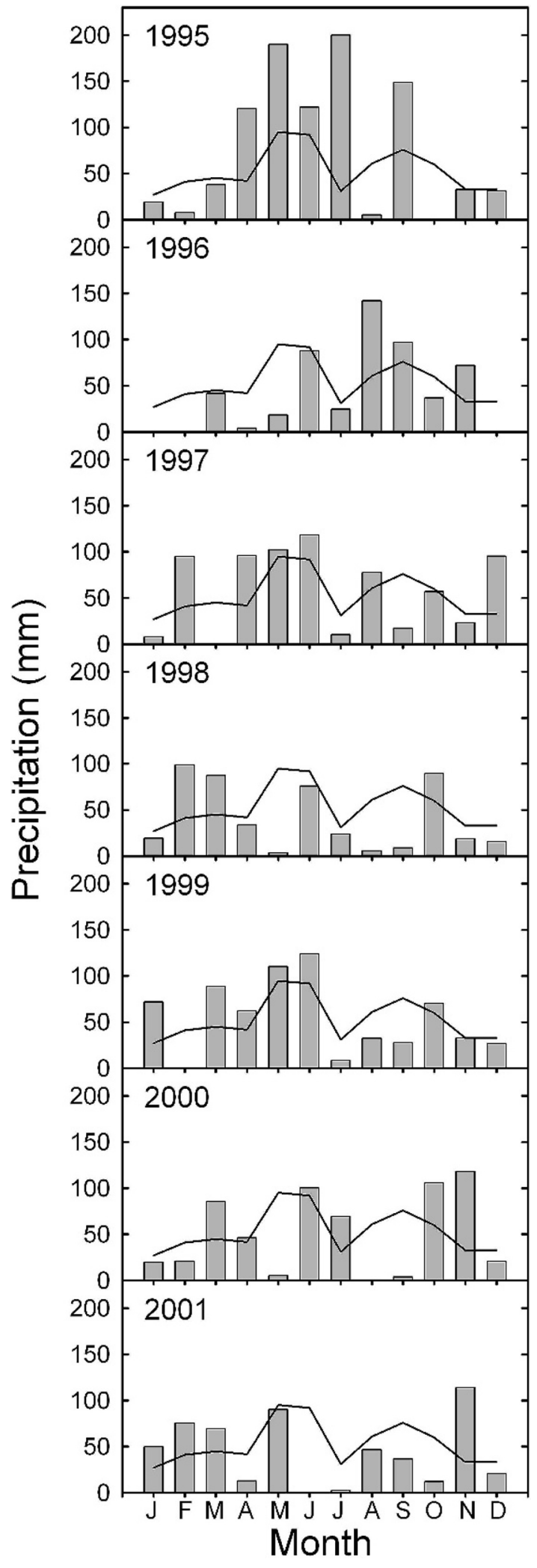

Figure 1. Monthly precipitation (bars) compared to the long-term mean monthly precipitation (line) for the Waggoner Experimental Ranch (WER), north central Texas, 1995 to 2001. Precipitation was recorded at several locations on the WER and averaged. 
Table 1. Characteristics of dominant soils on the Waggoner Experimental Ranch in Wilbarger County, Texas (from the US Department of Agriculture, Soil Conservation Service 1962).

\begin{tabular}{llll}
\hline \multicolumn{1}{c}{ Parameter } & \multicolumn{1}{c}{ Shallow-clay } & \multicolumn{1}{c}{ Clay-loam } & Loamy-bottom \\
\hline Catenal position & Ridgecrest and sideslope & Upland & Footslope \\
Permeability & Very slow, well drained & Slow, subject to crusting & Moderate, well drained \\
Hydrology & Run-off & Run-off & Run-on \\
Slope (\%) & $3-5$ & $1-5$ & $1-3$ \\
Site ID & R0 78 CY112 TX & R0 78 CY096 TX & R0 78CY103 TX \\
Soil series & Vernon complex & Tillman & Wheatwood \\
Taxonomic class & Fine, mixed, active, thermic Typic & Fine, mixed, superactive, thermic Typic & Fine-silty, mixed, active, thermic Fluventic \\
& Haplustept & Paleustoll & Haplustept \\
\hline
\end{tabular}

scale mesquite cover responses (Ansley et al. 2010) and livestock responses (Pinchak et al. 2010) to the same treatments.

\section{METHODS}

The study was conducted in the Rolling Plains ecological area of north-central Texas (Gould 1978) on the Waggoner Experimental Ranch (lat 33 $50^{\prime} \mathrm{N}$, long $99^{\circ} 5^{\prime} \mathrm{W}$; elevation $335-396 \mathrm{~m})$. Climate is continental with an average 220 frostfree days. Mean annual precipitation is $648 \mathrm{~mm}$ that is bimodally distributed with peaks in May $(95 \mathrm{~mm})$ and September (76 mm; Fig. 1). Mean monthly temperature varies from $3.9^{\circ} \mathrm{C}$ in January to $36.4^{\circ} \mathrm{C}$ in July. The $\mathrm{C}_{4}$ grass growing season is from April to September; $\mathrm{C}_{3}$ grass growth is primarily from September to November and February to May.

Prior to treatments, mesquite trees (canopy cover $15 \%$ to $40 \%$ ) dominated the vegetation matrix with small amounts of lotebush (Ziziphus obtusifolia [Hook. Ex. Torr. and A. Gray] A. Gray) and pricklypear cactus (Opuntia spp.). Herbaceous vegetation was dominated by the $\mathrm{C}_{3}$ mid-grass Texas wintergrass (Nassella leucotricha Trin. and Rupr.); $\mathrm{C}_{4}$ mid-grasses, silver bluestem (Bothriochloa laguroides DC.), sideoats grama (Bouteloua curtipendula [Michx.] Torr.), and meadow dropseed (Sporobolus compositus [Poir.] Merr.); the $\mathrm{C}_{4}$ short-grass, buffalograss (Buchloe dactyloides [Nutt.] Engelm.); the $\mathrm{C}_{3}$ annual Japanese brome grass (Bromus japonicus Thunb. Ex Murray); and forbs including western ragweed (Ambrosia psilostachya DC.), annual broomweed (Gutierrezia texana [DC.] Torr. and A. Gray), and heath aster (Aster ericoides L.). Nomenclature follows Diggs et al. (1999). Approximately $48 \%$ of soils were upland shallow-clays, $40 \%$ were upland clay-loams, and $12 \%$ were loamy-bottoms in riparian zones (Table 1). Mesquite trees were most dominant on clay-loam soils.

\section{Treatments and Management Protocol}

The experiment consisted of three landscape-scale treatments: 1) unburned continuously grazed control (UCC); 2) fenced four-paddock, one-herd rotation with fire (4:1F); and 3) fenced eight-paddock, one-herd rotation with fire $(8: 1 \mathrm{~F})$, with two replicates per treatment (replicate size range: 1294-2 130 ha). Land area of individual paddocks was adjusted during fencing to yield similar herbaceous production potential among paddocks in each $4: 1 \mathrm{~F}$ and $8: 1 \mathrm{~F}$ treatment replicate.
The initial fire management plan was to burn a different $25 \%$ of the production area of each treatment (i.e., one paddock in the 4:1 treatment; two paddocks in the $8: 1$ treatment) each year with high-intensity winter fires (February to March) to maximize mesquite and cactus top-kill. Grazing was to be deferred as much as possible during the 9 mo (May to January) prior to burning to accumulate herbaceous fuel within the paddock(s) targeted for burning. Costs of deferral were "internalized" by rotationally grazing cattle on the remaining $75 \%$ of each treatment without reducing the stocking rate predetermined for the entire system. Fire was to be applied when average or above-average precipitation resulted in sufficient fine fuel $\left(>2000 \mathrm{~kg} \cdot \mathrm{ha}^{-1}\right)$ to suppress mesquite (Ansley et al. 1998) and entire paddocks were burned. In drought years deferred paddocks were grazed instead of being burned. Fire treatments were only applied in the rotation treatments and not in the continuously grazed control. Prior to head fire ignition, 60-m wide blacklines were burned in December and January each year between parallel dozer lines cut on downwind sides of each burn unit.

Each replicate was stocked with a herd of commercial beef cows to calve in January through March. Calves were weaned and removed at the end of October and nonpregnant cows were replaced at weaning with 3-7-yr-old pregnant cows. Stocking rates were chosen to achieve moderate levels of grazing use in each treatment and were maintained at similar levels in all treatments during the study. Rates were initially set at $7.5 \mathrm{ha}$. animal unit ${ }^{-1} \cdot \mathrm{yr}^{-1}$ (ha $\cdot \mathrm{AUY}^{-1}$ ) in 1995 , but were reduced to 11-12 ha $\cdot \mathrm{AUY}^{-1}$ in 1997-1999 and 15 ha $\cdot \mathrm{AUY}^{-1}$ in 2000 following droughts.

We used the The Grazing Manager (TGM) optical utilization score (scale of 0 to 5) of Kothmann and Hinnant (1999) to decide when to move animals in each rotation-treatment replicate. Weekly visual assessments were made at 10 points in each paddock being grazed to determine the TGM utilization score. Cattle were moved out of unburned paddocks or paddocks that had been burned at least $1 \mathrm{yr}$ earlier when TGM $=2$ (moderate use of highly palatable forage, light use of mid-palatability forage, and negligible use of low-palatability forage). Newly burned paddocks were not grazed the first year postfire until grass reached $15-\mathrm{cm}$ height, and then were only lightly grazed (usually $2 \mathrm{~d}$ or $3 \mathrm{~d}$ ), and animals were moved when TGM = 1 (light use of highly palatable forage to $15-\mathrm{cm}$ height and negligible use of mid-palatability forage). They were lightly grazed again whenever grass regrowth had recovered to the same height. Cattle grazing days $\cdot \mathrm{ha}^{-1} \cdot \mathrm{yr}^{-1}$ were 
recorded in each paddock using the following formula: (no. head $\times$ no. days $/$ paddock size (ha). This resulted in each paddock being grazed 3-4 times on average each year.

Treatments began in early 1995 , and prescribed burns were conducted in 1996, 1997, 1998, and 2000. Due to drought and other weather-related factors, a lower number of fires were conducted than originally planned. In the 8:1F treatment, one different paddock in each replicate was burned in 1996 and 2000, and two paddocks in each replicate were burned in 1998 (eight paddocks total). In the $4: 1 \mathrm{~F}$ treatment, one paddock of one replicate was burned in 1996 and one paddock in the other replicate was burned in 1997. A second paddock in each replicate was burned in 1998, but no more paddocks were burned in the 4:1F treatment after that. Thus, a total of 12 paddocks were burned, four in each of the $8: 1 \mathrm{~F}$ replicates and two in each of the $4: 1 \mathrm{~F}$ replicates. Our original grazing and fire protocol would have prevented any burning after the 1996 fires because of numerous droughts. Therefore, in an attempt to apply some fires before funding ended, we deviated from original protocol and burned some paddocks in 1997, 1998, and 2000 under lower fine fuel loads and shorter prefire deferral periods.

\section{Vegetation Measurements}

Mesquite and cactus cover, total herbaceous standing crop, and bare ground cover were measured in March, July, and November each year in most burned paddocks and in two or three unburned paddocks in each treatment replicate. Sampling was conducted on 20 randomly located points along one 1000 $\mathrm{m}$-long transect randomly placed on each soil type in the measured paddocks. Herbaceous standing crop was estimated using the dry-weight-rank method of Mannetje and Haydock (1963), as modified by Jones and Hargreaves (1979) and described by Dowhower et al. (2001). At each sample point the three most productive grasses and forbs were ranked based on standing biomass within a $0.05-\mathrm{m}^{2}$ quadrat. Visual estimates of standing herbaceous biomass (live + dead; $\mathrm{g} \cdot \mathrm{m}^{-2}$ ) per species were made before the quadrat was clipped. All the clipped quadrats for each 1000-m transect were combined to yield a total transect dry weight after drying at $60^{\circ} \mathrm{C}$ to a constant weight (Dowhower et al. 2001). Visually estimated species composition from all quadrats was then multiplied by the total clipped biomass for each transect to calculate a species biomass estimate per transect. Bare ground and litter cover were visually estimated in each quadrat with bare ground, litter, and herbaceous cover totaling $100 \%$. As it took 2-3 wk to complete biomass sampling on all treatment replicates, grazing periods and sampling dates were not the same in each replicate. Possible confounding because of this was minimized by using the biomass of the whole replicate to compare with other replicates at each time of year sampling was conducted.

Mesquite and cactus canopy cover were estimated in the fall sample period at each herbaceous sampling point using a sampling technique developed by Dowhower et al. (2007) to assess potential mesquite and cactus influence at a particular point on the landscape. Each sample point was divided into four equal quadrants, and woody cover in each quadrant was assigned a 0,1 , or 2 score. If height of woody plants was less than $45^{\circ}$ vertically from the sample point, woody cover was considered to be minimal and was assigned a score of 0 . A score of 1 was assigned if woody cover partially filled a quadrant with an angle of $45^{\circ}$ to $75^{\circ}$ vertically from the sample point. A score of 2 was assigned if woody cover was $>75^{\circ}$ vertically from the sample point. Summing values for all four quadrants provided a score of 0 to 8 . Each rank score was considered the equivalent of $12.5 \%$ cover. Thus a score of 8 equaled $100 \%$ woody cover. Mesquite cover determined by this method compared favorably $\left(R^{2}=0.96\right)$ with the line-intercept method of Canfield (1941; Dowhower et al. 2007).

\section{Statistical Analyses}

It was logistically not possible to quantify vegetation responses in every paddock in each replicate. Therefore, we did not integrate vegetation responses across all paddocks (burned and unburned) in each of the three treatments (UCC: 4:1F, 8:1F). However, companion papers to this study quantified mesquite cover from aerial images and cattle responses that were integrated across all paddocks in the three treatments (Ansley et al. 2010; Pinchak et al. 2010).

For this paper, analysis was divided into two comparisons as subsets of the landscape-scale experiment. The first comparison determined the effects of fire on woody, cactus, and herbaceous vegetation over time and soil type. For this comparison, data from burned paddocks in all replicates of the rotation treatments $(4: 1 \mathrm{~F}$ and $8: 1 \mathrm{~F}$ combined) were compared to data from unburned paddocks in the rotation treatments as well as the unburned continuously grazed control. A repeated measures analysis of variance (ANOVA; PROC MIXED; Statistical Analysis System [SAS] 1990) was used to determine the main effects of treatment (fire vs. no fire; $n=2)$, soil type $(n=3$ ), and year $(n=7)$ on mesquite and cactus cover, and treatment $(n=2)$, soil type $(n=3)$, and sample date $(n=21 ; 7 \mathrm{yr} \times 3$ dates/yr) on herbaceous and bare ground responses. Figures 2 5 present data for this comparison and the treatments are referred to as "unburned paddocks" vs. "burned paddocks."

The second comparison determined the effects of grazing alone in the absence of fire in each of the three landscape-scale treatments (UCC: 4:1F, 8:1F). For this comparison, only unburned paddocks in the $4: 1 \mathrm{~F}$ and $8: 1 \mathrm{~F}$ treatments were compared to the UCC. A repeated measures ANOVA (PROC MIXED; SAS 1990) was used to determine the main effects of treatment $(n=3)$, replicates $(n=2)$, soil type $(n=3)$, and sample date $(n=21)$ on these variables. Tables 2 and 3 present data for this comparison and the treatments are referred to as $4: 1 \mathrm{~F}, 8: 1 \mathrm{~F}$, and unburned continuously grazed control.

Initial year data were used as covariables to adjust for antecedent conditions. Means were analyzed using Fisher's Protected LSD test if significant $(P \leq 0.05)$ interactions occurred among main effects. Means were considered significantly different at $P \leq 0.05$ unless otherwise noted. Mesquite and cactus cover data were tested for normality (Shapiro-Wilk test) and homogeneity of variance (Steel and Torrie 1980). No transformations were necessary.

Prefire herbaceous fine fuel was determined by comparing nondeferred and deferred paddocks in the $4: 1 \mathrm{~F}$ or $8: 1 \mathrm{~F}$ replicates that were burned in each year. Because of high variation in the number of paddocks included in this comparison from year to year, a one-way ANOVA analysis was conducted in years when $N>1$ in deferred and nondeferred paddocks (Table 4). 


\section{RESULTS}

\section{Climatic Conditions}

Mean annual air temperature was below the long-term mean $\left(17.3^{\circ} \mathrm{C}\right)$ from 1995 to $1997\left(16.9^{\circ} \mathrm{C}\right.$ to $\left.17.2^{\circ} \mathrm{C}\right)$ but was $1.5^{\circ} \mathrm{C}$ above the long-term mean from 1998 to 2001. Annual precipitation from 1995 to 2001 ranged from $407 \mathrm{~mm}$ to $914 \mathrm{~mm}$ (Fig. 1). The $\mathrm{C}_{4}$ grass growing season precipitation was well above average in 1995 but well below average in 1996, 1998, 2000, and 2001. Fall and winter precipitation was above normal in 1997/1998 and this, coupled with warmer winter temperatures, stimulated $\mathrm{C}_{3}$ grass growth during the 1998 fire season.

\section{Grazing Days and Prefire Herbaceous Fuel}

The number of grazing days $\cdot \mathrm{ha}^{-1} \cdot \mathrm{yr}^{-1}$ declined in the unburned continuously grazed control from 49.5 in 1995/1996 to 22.3 in 2001 (Table 5). The number of grazing days was lower in burned than unburned rotation-paddocks during the year of the burn after the 1996 fires (44.6 vs. 31.1) and 1998 fires (28.6 vs. 19.5 ) but not the first year after the 2000 fires. The number of grazing days in the 1996 burned paddocks was increased in 1998 and 1999, 2 yr and 3 yr postfire, compared to unburned rotation-paddocks. However, this trend was reversed in 2000. Grazing days were never increased in paddocks burned in 1997 or 1998 compared to unburned rotationpaddocks, but they were just 1 yr after the 2000 fires.

Prefire herbaceous fine fuel (grass +forbs) was greater $(P \leq 0.05)$ in deferred paddocks than nondeferred paddocks for the 1996 fires but was not different in the 1998 fires (Table 4). Sampling in deferred paddocks was limited to one paddock in 1997 and 2000, so statistical comparisons between deferred and nondeferred paddocks were not possible. The limited data suggest fine fuel was greater in deferred than nondeferred paddocks in 2000 but not in 1997 .

\section{Fire Effects}

Mesquite cover was reduced $(P \leq 0.05)$ by $72 \%, 28 \%$, and $32 \%$ on clay loam soils, by $33 \%, 36 \%$, and $53 \%$ on loamybottom soils, and by $25 \%, 39 \%$, and $79 \%$ on shallow-clay soils following fires in 1996, 1998, and 2000, respectively, when compared to unburned paddocks during the year of the fire, which we assume was similar to prefire mesquite cover levels in the burned paddocks (Fig. 2). Mesquite cover reductions by fire on clay-loam soils were greatest in 1996 when mesquite cover in unburned paddocks was $<25 \%$. The converse applied to the other two soil types where the 2000 fires caused the greatest cover reduction. Postfire rate of increase in mesquite cover differed between soil types $(P<0.001)$, and was greatest on clay-loam soils, but did not differ $(P>0.51)$ among burned and unburned paddocks on any soil type. Mesquite cover increased on clay-loam soils in unburned paddocks from $22 \%$ to $40 \%$ in 6 yr (1995-2001), an average of 3.0 percentage units per year. Cover increases on loamy-bottom and shallow-clay soils in unburned paddocks were 1.2 and 0.4 percentage units per year, respectively.

Cactus cover was $<1 \%$ on all soil types except clay-loam soils, so we report results from clay-loam soils only. Cactus cover was reduced $(P \leq 0.05)$ following fires in 1996, 1998, and 2000

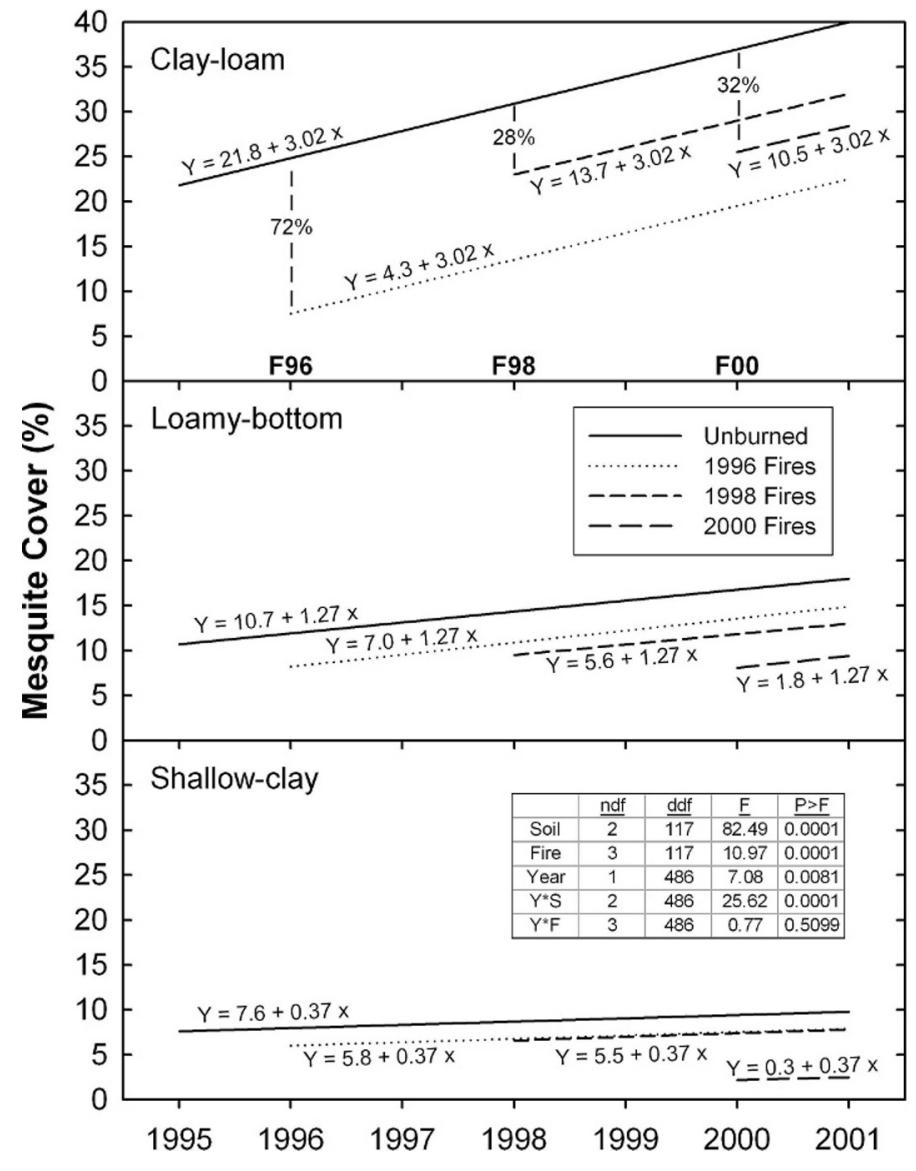

Figure 2. Mesquite canopy cover changes over time in unburned paddocks and paddocks burned in 1996, 1998, or 2000 on three soil types. Vertical lines with percentage values in the top panel represent the percent reduction in mesquite cover by fire in each of the fire years compared to the unburned paddocks (values are not shown in the other panels but are reported in the text).

(Fig. 3). Following the 1996 fires, cactus cover increased faster in burned than unburned paddocks so that there was no difference $(P>0.05)$ in cactus cover by 2001 . Rate of increase in cactus cover in burned paddocks following the 1998 and 2000 fires was similar $(P>0.05)$ to unburned paddocks.

Significant interactions occurred between fire (burned vs. unburned paddocks), year, and soil type with respect to total herbaceous biomass responses. Herbaceous biomass on clayloam soils was lower in burned than unburned paddocks in March and July 1996, the first growing season after the 1996 fires, but recovered to levels similar to the unburned paddocks by November 1996 (Fig. 4). After 1996, herbaceous biomass was greater $(P \leq 0.05)$ in burned than unburned paddocks on 3 of 12 sample dates and was not different between treatments on the remaining nine dates. Long-term postfire herbaceous biomass recovery was slower on this soil type following the 1998 fires. After the first year postfire in 1998, herbaceous biomass was lower $(P \leq 0.05)$ in burned than unburned paddocks on two of eight dates, with no differences on the remaining six dates. Following the 2000 fires, herbaceous biomass was lower $(P \leq 0.05)$ in burned than unburned paddocks on one of the two dates measured after the first year 


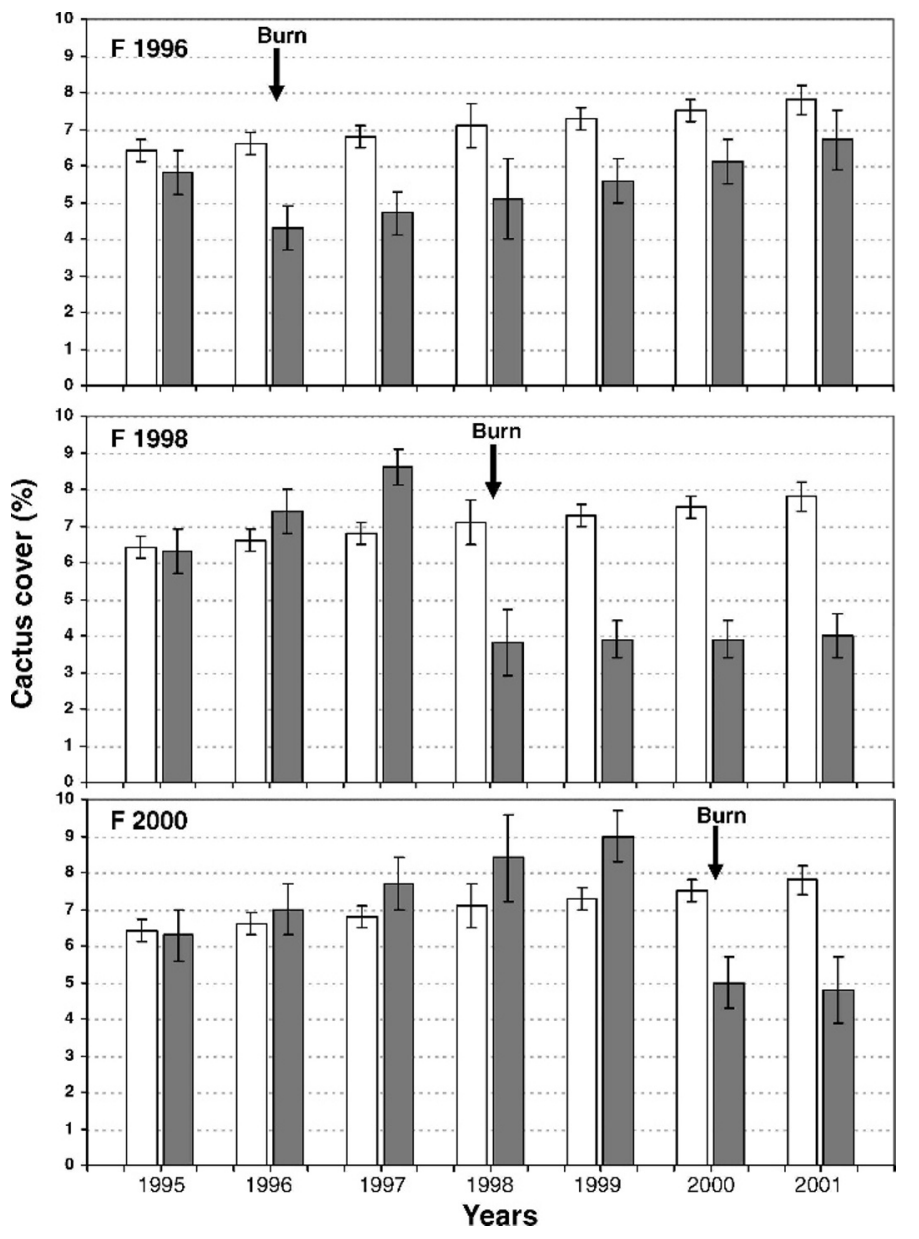

Figure 3. Mean cactus cover ( $\pm \mathrm{SE}$ ) on clay-loam soils in unburned paddocks (open bars) and paddocks burned in 1996, 1998, and 2000 (solid bars). Arrows indicate when burns were implemented.

postfire. In comparing all fires, herbaceous biomass after the first year postfire was not different $(P \leq 0.05)$ between burned and unburned paddocks on 16 of the 22 possible sample periods.

There was a significant $(P \leq 0.05)$ treatment $\times$ soil type $\times$ year interaction with respect to bare ground responses. As expected, bare ground cover increased $(P<0.0001)$ on all soil types immediately after fires in all years (Fig. 5). Paddocks burned in 2000 had few shallow-clay areas, so these soils were not sampled for the year 2000 fires. Postfire bare ground recovery to unburned paddock levels was slowest after the 1998 fires; recovery took 16, 28, and 16 mo on loamy-bottom soils, and 20,32, and 12 mo on clay-loam soils following the 1996, 1998, and 2000 fires, respectively. Bare ground on shallow-clay soils was slow to recover to unburned levels after both the 1996 and 1998 fires.

\section{Grazing Effects Without Fire}

Total grass biomass, averaged over $7 \mathrm{yr}$, was greater $(P \leq 0.05)$ in unburned paddocks in the $8: 1 \mathrm{~F}$ treatment than in the unburned continuously grazed control on loamy-bottom soils (Table 2). This difference was not found on other soils in the $8: 1 \mathrm{~F}$ treatment or on any soil type in the $4: 1 \mathrm{~F}$ treatment. Forb biomass was slightly lower $(P \leq 0.054)$ in unburned paddocks

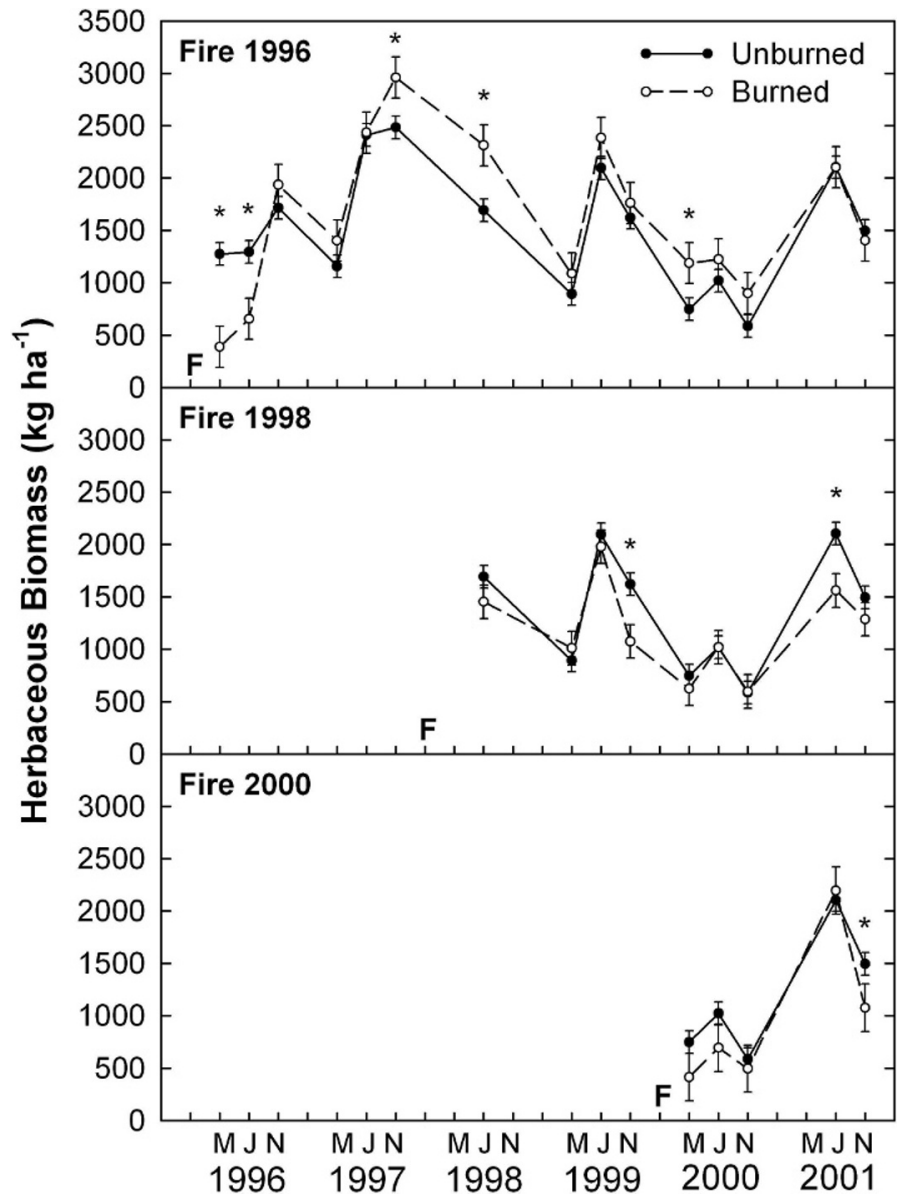

Figure 4. Postfire mean total herbaceous biomass ( \pm SE) on clay-loam soils in unburned paddocks (solid line) and paddocks burned in 1996, 1998, or 2000 (dashed line). Dates are March (M), July (J), and November (N) of each year. "F" indicates when fire was applied. Asterisk indicates significant difference $(P \leq 0.05)$.

in the $4: 1 \mathrm{~F}$ treatment than in the continuously grazed control on shallow-clay soils. On clay-loam soils there were no differences $(P>0.154)$ in grass or forb biomass between unburned paddocks in the rotation treatments and the continuously grazed control.

Bare ground cover, averaged over all $7 \mathrm{yr}$, was influenced by soil type $(P<0.0001)$ and grazing treatment $(P=0.0013)$. Unburned paddocks in the $8: 1 \mathrm{~F}$ treatment had lower $(P \leq 0.005)$ bare ground cover on both loamy-bottom and clay-loam soils than the unburned continuously grazed control (Table 3). There was no difference $(P \leq 0.05)$ in bare ground between unburned paddocks in the $4: 1 \mathrm{~F}$ treatment and the unburned continuously grazed control.

\section{DISCUSSION}

This paper and companion papers (Ansley et al. 2010; Pinchak et al. 2010) provide vegetative and livestock response data that are needed to develop an understanding of how effective fire can be in reducing mesquite and cactus cover, and how to manage livestock grazing to achieve desirable ecological and economic goals using fire. 

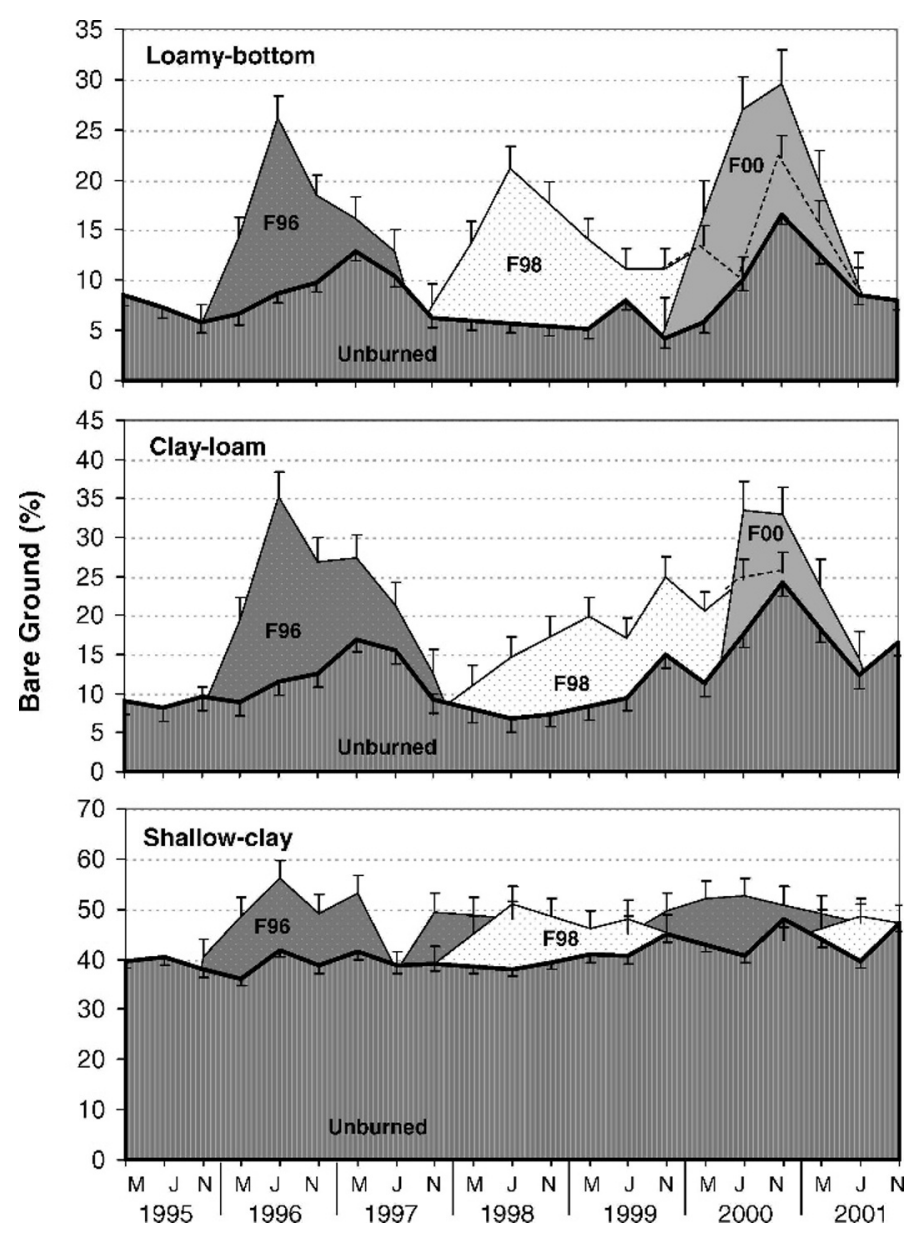

Figure 5. Mean bare ground cover $( \pm S E)$ on three soil types in unburned paddocks and paddocks burned in 1996 (F96), 1998 (F98), and 2000 (F00). Dates are March (M), July (J), and November (N) of each year. Fire did not occur on shallow clay soils in 2000 .

The brush treatment used was prescribed fire because it is low-cost and potentially has better long-term economics than other treatment options (Teague et al. 2001). Our use of rotational grazing in multipaddock systems in this study had three purposes: 1) to defer grazing and accumulate herbaceous fine fuel in paddocks targeted to be burned, 2) to protect recently burned paddocks from heavy grazing until grasses had recovered from the fire disturbance, and 3) to graze olderburned paddocks, which should be more productive due to mesquite suppression, for longer intervals than unburned paddocks as part of the cost of internalizing the grazing deferment of new paddocks targeted for fire. Essential to this plan was that the cost of prefire grazing deferment to accumulate fine fuel in paddocks to be burned was internalized in each rotationally grazed system (i.e., treatment) by temporarily grazing all cattle stocked for the entire system on the portion of the system not targeted for burning. Given the annual precipitation level $(648 \mathrm{~mm})$ in our region, we estimated that $25 \%$ of the production area of a multipaddock system (one paddock in a four-paddock system or two paddocks in an eightpaddock system) could be burned, and cattle, stocked moderately for the entire system, could be temporarily concentrated on the remaining $75 \%$ of the system, under normal climatic conditions.

Grazing days data (Table 5) indicate that burned paddocks were grazed less than unburned paddocks during the first year postfire, and that the older, 1996-burned paddocks with more forage provided proportionately more grazing days before reaching the TGM utilization score of 2 than the unburned rotation-paddocks in 1998 and 1999. These and herbaceous biomass data (Fig. 4) provide indirect evidence that herbaceous production was greater in the 1996-burned paddocks than unburned rotation-paddocks in these years. Increases in grazing days were not evident in paddocks burned in 1998, because these fires were less effective than the 1996 fires in reducing mesquite cover, but did occur 1 yr after the 2000 fires.

Because of growing season droughts, increases in mesquite cover that limited herbaceous fine fuel accumulation, and wet winter conditions that reduced fire intensity by causing $\mathrm{C}_{3}$ grasses to green up, we were not able after 1996 to burn as frequently or achieve the degree of mesquite cover reduction by fire that was desired. Moreover, although we reduced cattle stocking rate for all treatments twice during the study period due to drought, our initial stocking rate was too high to cope with the extreme drought in spring and early summer of 1996, the first growing season after the first fires in February 1996. This drought essentially eliminated grazing in burned paddocks for the first 6 mo after the fires and highlighted the importance of a more conservative initial stocking rate. Teague et al. (2008c) conducted a simulation analysis over a 30-yr period using actual weather data and the biological data generated in

Table 2. Grass and forb biomass (mean \pm SE) in unburned paddocks of the three landscape treatments on each soil type (averaged from 1995 to 2001; Waggoner Experimental Ranch). $P$ values are relative to the continuously grazed control.

\begin{tabular}{|c|c|c|c|c|c|c|}
\hline \multirow[b]{3}{*}{ Plant category } & \multirow[b]{3}{*}{ Soil type } & \multicolumn{5}{|c|}{ Treatment $^{1}$} \\
\hline & & \multirow[b]{2}{*}{ UCC $\left(\mathrm{kg} \mathrm{ha}^{-1}\right)$} & \multicolumn{2}{|c|}{$4: 1 \mathrm{~F}$} & \multicolumn{2}{|c|}{$8: 1 F$} \\
\hline & & & $\left(\mathrm{kg} \cdot \mathrm{ha}^{-1}\right)$ & $P>t^{2}$ & $\left(\mathrm{~kg} \cdot \mathrm{ha}^{-1}\right)$ & $P>t^{2}$ \\
\hline \multirow[t]{3}{*}{ Grass } & Loamy-bottom & $1835 \pm 39$ & $1868 \pm 34$ & 0.547 & $1991 \pm 47$ & 0.048 \\
\hline & Clay-loam & $1338 \pm 36$ & $1264 \pm 38$ & 0.212 & $1322 \pm 37$ & 0.774 \\
\hline & Shallow-clay & $940 \pm 24$ & $908 \pm 20$ & 0.352 & $992 \pm 28$ & 0.212 \\
\hline \multirow[t]{3}{*}{ Forb } & Loamy-bottom & $450 \pm 21$ & $416 \pm 17$ & 0.262 & $419 \pm 22$ & 0.370 \\
\hline & Clay-Ioam & $343 \pm 18$ & $299 \pm 20$ & 0.154 & $304 \pm 19$ & 0.197 \\
\hline & Shallow-clay & $318 \pm 15$ & $272 \pm 12$ & 0.054 & $291 \pm 0.6$ & 0.266 \\
\hline
\end{tabular}

${ }^{1}$ UCC indicates unburned continuously grazed control; 4:1F indicates fenced four-paddock, one-herd rotation with fire; and 8:1F indicates fenced eight-paddock, one-herd rotation with fire. ${ }^{2}$ Relative to continuously grazed control. 
Table 3. Bare ground (mean \pm SE) in unburned paddocks of the three landscape treatments on each soil type (averaged from 1995 to 2001; Waggoner Experimental Ranch). $P$ values are relative to the continuously grazed control.

\begin{tabular}{|c|c|c|c|c|c|}
\hline \multirow[b]{3}{*}{ Soil type } & \multicolumn{5}{|c|}{ Treatment } \\
\hline & \multirow[b]{2}{*}{ UCC (\%) } & \multicolumn{2}{|c|}{$4: 1 F$} & \multicolumn{2}{|c|}{$8: 1 F$} \\
\hline & & $\%$ & $P>t^{1}$ & $\%$ & $P>t^{1}$ \\
\hline Loamy-bottom & $9.3 \pm 0.3$ & $8.3 \pm 0.3$ & 0.064 & $6.8 \pm 0.3$ & 0.004 \\
\hline Clay-Ioam & $13.4 \pm 0.5$ & $13.3 \pm 0.6$ & 0.952 & $9.7 \pm 0.3$ & 0.002 \\
\hline Shallow-clay & $41.8 \pm 0.6$ & $41.0 \pm 0.5$ & 0.363 & $39.7 \pm 0.3$ & 0.062 \\
\hline
\end{tabular}

${ }^{1}$ Relative to continuously grazed control.

this study and found that to achieve the highest net returns, our initial stocking rate should have been $20 \%$ lower.

In spite of these obstacles, data from the rotationally grazed and burned treatments $(4: 1 \mathrm{~F}$ and $8: 1 \mathrm{~F})$ revealed that 1$)$ mesquite cover was reduced to some degree on all soil types in paddocks that were burned, 2) total herbaceous production was either not affected or increased in unburned rotationpaddocks, and 3) bare ground was either not affected or was reduced in unburned rotation-paddocks. Thus, the concentration of grazing on $75 \%$ of the area of rotational-grazed treatments during the prefire deferment period, or later in the study as drought continued, on $87.5 \%$ of the area of the $8: 1 \mathrm{~F}$ treatment, was either not detrimental to or slightly enhanced some aspects of the herbaceous community. In this regard, the numerous nonsignificant $(P>0.05)$ results in comparisons of herbaceous responses in unburned paddocks in the $4: 1 \mathrm{~F}$ or $8: 1 \mathrm{~F}$ treatments vs. the unburned continuously grazed control (Tables 2 and 3) are important because they indicate that some mesquite and cactus suppression was achieved without a detrimental effect on the herbaceous community.

In contrasting the two rotational systems, $4: 1 \mathrm{~F}$ and $8: 1 \mathrm{~F}$, it became more apparent as drought continued that we could not internalize grazing deferment on $75 \%$ of the total system area (the $4: 1 \mathrm{~F}$ treatment), but could on $87.5 \%$ of the system area if we burned one paddock instead of two in the 8:1F treatment. This was manifest in the year 2000, when we were able to burn one paddock in each $8: 1 \mathrm{~F}$ replicate $(12.5 \%$ of total area) but could not accumulate sufficient fine fuel to burn a paddock ( $25 \%$ of total area) in the $4: 1 \mathrm{~F}$ treatment.

\section{Mesquite and Cactus Responses}

The rate that mesquite cover increased over time was principally governed by soil type and was much greater on clay-loam soils $(22 \%$ to $40 \%$ in $6 \mathrm{yr})$ where most mesquite occurs and is most problematic (Ansley et al. 2001; Asner et al. 2003). An unexpected result was that the rate of mesquite cover increase was similar between years even though the site experienced a wide variation in growing season precipitation during the study. This may be due to above normal precipitation received during several fall and winter periods during the study that recharged soil moisture (Wilcox et al. 2006). The dry summers experienced in this study also possibly reduced the competitiveness of summer growing $\mathrm{C}_{4}$ grasses allowing mesquite to increase faster. Simmons et al. (2007), working in this area, indicated that grasses compete significantly with mesquite to decrease its rate of growth. Another
Table 4. Prefire herbaceous total (grass +forb) standing crop (mean $\pm \mathrm{SE}$ ) in deferred and nondeferred paddocks averaged over all 4:1 and 8:1 rotation systems. Nondeferred paddocks do not include previously burned paddocks. Treatments with similar letters in each year are not significantly different at $P \leq 0.05$. $N=$ number of paddocks evaluated.

\begin{tabular}{ccccccc}
\hline & \multicolumn{2}{c}{ Deferred paddocks } & & & \multicolumn{2}{c}{ Nondeferred paddocks } \\
\cline { 2 - 3 } \cline { 5 - 6 } Burn year & Mean \pm SE $\left(\mathrm{kg} \cdot \mathrm{ha}^{-1}\right)$ & $N$ & & Mean \pm SE $\left(\mathrm{kg} \cdot \mathrm{ha}^{-1}\right)$ & $N$ \\
\hline 1996 & $3574 \pm 163 \mathrm{a}$ & 3 & & $2297 \pm 184 \mathrm{~b}$ & 8 \\
$1997^{1}$ & 1677 & 1 & & $1545 \pm 399$ & 3 \\
$1998^{2}$ & $2262 \pm 203 \mathrm{a}$ & 4 & & $2131 \pm 241 \mathrm{a}$ & 4 \\
$2000^{3}$ & 2492 & 1 & & $1279 \pm 160$ & 5 \\
\hline
\end{tabular}

${ }^{1}$ One paddock was burned in 1997.

${ }^{2}$ Prefire fuel data were collected in four of the six paddocks that were burned in 1998. ${ }^{3}$ Prefire fuel data were collected in one of the two paddocks that were burned in 2000 .

unexpected result was that the rate of increase of mesquite cover after fire was the same as that of the unburned paddocks within each soil type (Fig. 2). Mesquite plants likely were resprouting from existing mature root systems rather than having to re-establish from seed (Ansley et al. 1998).

Increasing mesquite cover probably limited the effectiveness of fires on clay-loam soils. The first fires in 1996, when mesquite cover was $25 \%$, reduced cover by $72 \%$ (from $25 \%$ to $7 \%$ ). In contrast, mesquite cover in unburned paddocks had increased to $31 \%$ and $37 \%$ by the time of the 1998 and 2000 fires, respectively. Fires in 1998 and 2000 reduced cover by only $28 \%$ and $32 \%$, respectively. We did not see this trend on the other soil types. Mesquite cover on these soils never exceeded $20 \%$ in unburned paddocks, and other factors besides increasing cover must have influenced the variable effects of fire. The highest percent reduction in cover on these soils occurred during the 2000 fires.

Pricklypear cactus cover was reduced by the winter fire treatments, but large mottes were mostly unaffected. In addition, increases in pricklypear cover were faster following the 1996 fires than in unburned paddocks. This is consistent with work by Ansley and Castellano (2007b) who reported that winter fires killed a low percentage of pricklypear and regrowth following winter fires was rapid. Pricklypear mortality was higher, and re-invasion rates were lower following summer fires than winter fires (Ansley and Castellano 2007b).

\section{Herbaceous Responses}

The time it takes for herbaceous standing biomass to recover after fire is dependent on postfire weather conditions (Wright 1974; Teague et al. 2008b). In this study, we found that the time required for total herbaceous (live + dead) biomass in burned paddocks to return to levels in the unburned paddocks was one full growing season after the 1996 fires (Fig. 4). First year postfire differences in herbaceous biomass between burned and unburned paddocks were less after the 1998 and 2000 fires than the 1996 fires; this may have been due to slightly more April and May precipitation in 1998 and 2000 than in 1996, although all 3 yr experienced growing season droughts. Ansley et al. (2006) and Ansley and Castellano (2007a) found that when postfire grazing was eliminated, grasses common to this region (sideoats grama, Texas wintergrass, and buffalograss) required 1-2 yr before total (live + dead) standing biomass was 
Table 5. Cattle grazing days $\cdot \mathrm{ha}^{-1} \cdot \mathrm{yr}^{-1}$ (mean $\pm \mathrm{SE}$ ) in the unburned, continuously grazed control (UCC); unburned (UB) paddocks; and burned (1996F, 1997F, 1998F, and 2000F) paddocks in the rotationally grazed (RG) treatments on the Waggoner Experimental Ranch in the Texas Rolling Plains. Bold text indicates prefire data.

\begin{tabular}{|c|c|c|c|c|c|c|c|}
\hline Treatment & 1995 & 1996 & 1997 & 1998 & 1999 & 2000 & 2001 \\
\hline UCC $(n=2)$ & $49.5 \pm 0.4$ & $48.8 \pm 2.0$ & $29.7 \pm 2.8$ & $28.5 \pm 0.3$ & $21.9 \pm 0.7$ & $23.7 \pm 0.4$ & $22.3 \pm 0.5$ \\
\hline RG-UB $(n=10)^{1}$ & $47.6 \pm 3.2$ & $44.6 \pm 1.8$ & $32.4 \pm 3.5$ & $28.6 \pm 2.8$ & $22.6 \pm 2.0$ & $26.0 \pm 1.8$ & $18.1 \pm 1.2$ \\
\hline $\mathrm{RG}-1996 \mathrm{~F}(n=3)^{2}$ & $45.6 \pm 11.8$ & $31.1 \pm 2.7$ & $27.0 \pm 4.8$ & $40.1 \pm 1.7$ & $34.4 \pm 10.8$ & $16.8 \pm 1.1$ & $24.9 \pm 8.4$ \\
\hline $\mathrm{RG}-1997 \mathrm{~F}(n=1)$ & 39.4 & 37.8 & 22.9 & 29.6 & 21.7 & 18.8 & 6.1 \\
\hline $\mathrm{RG}-1998 \mathrm{~F}(n=6)$ & $49.4 \pm 4.6$ & $51.8 \pm 5.2$ & $20.5 \pm 2.3$ & $19.5 \pm 2.6$ & $22.5 \pm 3.4$ & $23.4 \pm 2.2$ & $20.7 \pm 1.1$ \\
\hline $\mathrm{RG}-2000 \mathrm{~F}(n=2)$ & $61.0 \pm 5.9$ & $65.9 \pm 11.9$ & $29.7 \pm 11.5$ & $22.7 \pm 13.7$ & $23.7 \pm 2.6$ & $22.9 \pm 0.3$ & $28.3 \pm 2.3$ \\
\hline
\end{tabular}

${ }^{1}$ Ten paddocks were selected (one from each $4: 1 \mathrm{~F}$ and four from each $8: 1 \mathrm{~F}$ replicate) that remained unburned throughout the study.

${ }^{2}$ One replicate of the $4: 1 \mathrm{~F}$ was burned in 1997 and was not included in the $1996 \mathrm{~F}$ means.

similar to the unburned treatment after intense winter fires. Thus, postfire herbaceous recovery rates under drought conditions in the current study could be viewed as typical or even slightly accelerated. The fire-caused reduction in mesquite, combined with periodic rest provided by rotational grazing, likely facilitated postfire herbaceous recovery rates. Our study did not have a treatment where grazing was completely deferred after fire to make this conclusion absolute, however.

After the first year postfire recovery period, where grazing in recently burned paddocks was limited to allow herbaceous recovery, burned paddocks were grazed a greater number of days than unburned paddocks in both the $4: 1 \mathrm{~F}$ and $8: 1 \mathrm{~F}$ treatments to take advantage of the increased herbaceous production due to mesquite suppression. This may partially explain why, after the first growing season postfire, there were many more dates (16 of 22) when herbaceous biomass was not different $(P \leq 0.05)$ between burned and unburned paddocks than when it was different (Fig. 4). The overall lack of differences may have been the result of frequent livestock rotations into the burned paddocks that captured any enhanced herbaceous growth resulting from mesquite reduction or nutrient enhancement by fire. The three dates after the 1996 fires where herbaceous biomass was greater $(P \leq 0.05)$ in burned than unburned paddocks indicate a strong response to reduction of mesquite cover by these fires. This enhancement of herbaceous biomass by fire did not occur after the 1998 or 2000 fires. This could be attributed to several factors, including effects of extended droughts, lower mesquite cover reduction, or possibly overutilization of the burned paddocks. The importance of these responses at the multipaddock or "management system" level was that any additional grazing in older burned paddocks was probably instrumental in allowing more prefire deferment time for paddocks to be burned without overgrazing the unburned paddocks. The extra grazing in burned paddocks in the rotation treatments partially explains why there was no reduction in grass biomass in unburned rotation-paddocks compared to the unburned continuously grazed control (Table 2).

\section{Bare Ground Responses}

Fire increased bare ground cover and it took 12-32 mo for bare ground cover to decrease to levels in unburned paddocks. Droughts coupled with periodic grazing in burned paddocks contributed to the slow reduction of bare ground to unburned paddock levels. Change in bare ground cover is a good indicator of rangeland health and hydrological function (Bakker et al. 1983; Thurow 1991; Fuls 1992; Kellner and Bosch 1992; Snyman 1998; Teague et al. 2008b).

Effects of rotational grazing alone in unburned paddocks in the $4: 1 \mathrm{~F}$ and $8: 1 \mathrm{~F}$ treatments were neutral or positive on reducing bare ground cover despite the increased grazing pressure in these paddocks in order to defer grazing in other paddocks to be burned. The degree to which periodic rest from grazing ameliorated the negative impacts of the increased grazing pressure on bare ground is unknown. However, bare ground cover in unburned paddocks in the $8: 1 \mathrm{~F}$ treatment decreased $(P \leq 0.05)$ relative to the unburned continuously grazed control on the two most productive soil types. Periodic rest from grazing during the growing season is important for rangeland restoration and maintenance (Snyman 1998; Teague et al. 2004; Müller et al. 2007) and may have contributed to lowering bare ground in this treatment.

\section{MANAGEMENT IMPLICATIONS}

Our results indicate that a one-herd, multiple-paddock rotational grazing system is one possible strategy to facilitate accumulation of herbaceous fine fuel for prescribed fire to reduce woody cover and to regulate postfire grazing pressure to accelerate grass recovery. For this semiarid ecosystem $(648 \mathrm{~mm}$ annual precipitation), the $8: 1 \mathrm{~F}$ treatment was functionally more useful than the $4: 1 \mathrm{~F}$ for internalized grazing deferment to facilitate the application of fire without degrading the herbaceous understory. We did not achieve the degree of mesquite cover reduction or the frequency of burning that was desired. This was due to summer droughts, the high levels of mesquite at the start of the study, and the rapid increases in mesquite cover that limited the accumulation of herbaceous fine fuel for fire. In addition, wet winter conditions reduced intensity of some fires that were applied. Severe drought the first growing season after the first fires in 1996 stopped grass growth in burned paddocks for most of the growing season and limited our management options because we were stocked too heavily. Thus, the importance of a lower initial stocking rate is imperative in drought-prone regions if fire is to be used for suppressing woody species and grazing deferment for fire is internalized within the management unit.

The increase in mesquite over the experimental period and its increasingly negative impact on herbaceous production illustrate the need to use fire when mesquite cover is low (Perrings 
and Walker 1997; Teague et al. 2001; Higgins et al. 2007). Teague et al. (2003) have indicated that fire is most effective, and net financial benefits for reducing mesquite with fire are greatest, when mesquite cover is no more than $10 \%$ to $15 \%$. More expensive means of treating mesquite, such as with herbicides, are necessary with higher mesquite cover. An initial chemical treatment of mesquite followed by fire was probably a better, although more costly, option (Teague et al. 2001, 2003; Ansley et al. 2004, 2010).

\section{ACKNOWLEDGMENTS}

The authors gratefully acknowledge the facilities and livestock made available by W. T. Waggoner Estate. We thank Rob Borchardt, Cody Bradley, Michel Bryant, Justin Clarey, Bob Cross, Diane Conover, David Echels, Joelyn Foy, Russell Fritsch, Tracy Gwaltney, Jason Hohlt, Eli Ornelas, Gerral Schulz, Riley Shoaf, Gina Spratt, Dustin Stacey, John Todd, Tim Tunnel, Dan Vasquez, and Jan Worrall for technical assistance. The project is indebted to the competent inputs of Waggoner Ranch staff, particularly Weldon Hawley, Dee Robinson, and Anne Pilcher.

\section{LITERATURE CITED}

Andales, A. A., J. D. Derner, L. R. Ahuja, and R. H. Hart. 2006. Strategic and tactical prediction of forage production in Northern Mixed-Grass Prairie. Rangeland Ecology and Management 59:576-584.

Ansley, R. J., and M. J. Castellano. 2007a. Texas wintergrass and buffalograss response to seasonal fires and clipping. Rangeland Ecology and Management 60:154-164

Ansley, R. J., and M. J. Castellano. 2007b. Prickly pear mortality and regrowth following seasonal fires. Rangeland Ecology and Management 60:244-252.

Ansley, R. J., M. J. Castellano, and W. E. Pinchak. 2006. Sideoats grama growth responses to seasonal fires and clipping. Rangeland Ecology and Management 59:258-266.

Ansley, R. J., AND P. W. JacoBy. 1998. Manipulation of fire intensity to achieve mesquite management goals in north Texas. In: T. L. Pruden and L. A. Brennan [EDS.]. Fire in ecosystem management: shifting the paradigm from suppression to prescription. Tall Timbers Fire Ecology Conference Proceedings, No. 20. Tallahassee, FL, USA: Tall Timbers Research Station. p. 195-204.

Ansley, R. J., D. L. Jones, T. R. Tunnell, B. A. Kramp, and P. W. Jacoby. 1998. Honey mesquite canopy responses to single winter fires: relation to fine fuel, weather and fire temperature. International Journal of Wildland Fire 8:241-252.

Ansley, R. J., W. E. Pinchak, W. R. Teague, B. A. Kramp, D. L. Jones, and K. Barnett. 2010. Integrated grazing and prescribed fire restoration strategies in a mesquite savanna: II. Fire behavior and mesquite landscape cover responses. Rangeland Ecology and Management 63:286-297.

Ansley, R. J., W. E. Pinchak, W. R. Teague, B. A. Kramp, D. L. Jones, and P. W. Jacoby 2004. Long-term grass yields following chemical control of honey mesquite. Journal of Range Management 57:49-57.

Ansley, R. J., And C. A. Taylor. 2004. The future of fire as a tool for managing brush. In: W. T. Hamilton, A. McGinty, D. N. Ueckert, C. W. Hanselka, and M. R. Lee [EDS.]. Brush management: past, present and future. College Station, TX, USA: Texas A\&M University Press. p. 200-212.

Ansley, R. J., X. B. Wu, and B. A. Kramp. 2001. Observation: long-term increases in mesquite canopy cover in a north Texas savanna. Journal of Range Management 54:171-176.

ArcheR, S. 1995. Herbivore mediation of grass-woody interactions. Tropical Grasslands 29:218-235.

Archer, S., T. W. Boutton, and K. A. HibBard. 2001. Trees in grasslands: biogeochemical consequences of woody plant expansion. In: E. D. Schulze, S. Harrison, M. Heimann, E. Holland, J. Lloyd I, and D. Schimel [EDS.]. Global biogeochemical cycles in the climate system. San Diego, CA, USA: Prentice. $p$. 115-138.

Asner, G. P., S. R. Archer, R. F. Hughes, R. J. Ansley, and C. A. Wessman. 2003. Net changes in regional woody vegetation cover and carbon storage in Texas drylands. Global Change Biology 9:316-335.

Bakker, J. P., J. F. de Leeuw, and S. E. Von Weiren. 1983. Micro-patterns in grassland vegetation created and sustained by sheep. Vegetatio 55:153-161.

Blackburn, W. H., and P. T. Tueller. 1970. Pinyon and juniper invasion in black sagebrush communities in east-central Nevada. Ecology 51:841-848.

Canfield, R. H. 1941. Application of the line intercept method in sampling range vegetation. Journal of Forestry 39:388-394.

Collins, S. L., A. K. Knapp, J. M. Briggs, J. M. Blair, and E. M. Steinaur. 1998. Modulation of diversity by grazing and mowing in native tall grass prairie. Science 280:745-747.

DigGs, G. M., B. L. Lipscomb, and R. J. O'Kennon. 1999. Illustrated flora of north central Texas. Fort Worth, TX, USA: Botanical Research Institute of Texas. $1623 \mathrm{p}$.

Dowhower, S. L., W. R. Teague, R. J. Ansley, and W. E. Pinchak. 2001. Dry-weightrank method assessment in heterogeneous communities. Journal of Range Management 54:71-76.

Dowhower, S. L., W. R. Teague, S. A. Gerrard, and D. M. Conover. 2007. Angle cover class: a variable plot technique for estimating shrub quantities in rangeland areas. Arid Land Research and Management 21:343-358.

Futs, E. R. 1992. Ecosystem modification created by patch-overgrazing in semiarid grassland. Journal of Arid Environments 23:59-69.

GouLd, F. W. 1978. The grasses of Texas. College Station, TX, USA: Texas A\&M University Press. $267 \mathrm{p}$

Hamilton, W. T., and D. N. Ueckert. 2004. Rangeland woody plant and weed management-past, present, and future. In: W. T. Hamilton, A. McGinty, D. N. Ueckert, C. W. Hanselka, and M. R. Lee [EDs.]. Brush management: past, present and future. College Station, TX, USA: Texas A\&M University Press. p. 3-13.

Higgins, I. H., J. Kantelhardt, S. Scheiter, and J. Boerner. 2007. Sustainable management of extensively managed savanna rangelands. Ecological Economics 62:102-114.

Jones, R. M., And J. N. G. HaRgreaves. 1979. Improvements to the dry-weight-rank method for measuring botanical composition. Grass and Forage Science $34: 181-189$

KELLnER, K., AND O. J. H. BosCH. 1992. Influence of patch formation in determining stocking rate for southern African grasslands. Journal of Arid Environments 22:99-105.

Kothmann, M. M., and R. T. Hinnant. 1999. The grazing manager for Windows. College Station, TX, USA: Department of Rangeland Ecology and Management, Texas A\&M University. $40 \mathrm{p}$.

Kramp, B. A., R. J. Ansley, and T. R. Tunnell. 1998. Survival of mesquite seedlings emerging from cattle and wildlife feces in a semi-arid grassland. Southwestern Naturalist 43:300-312.

Laxson, J. D., W. H. Schacht, and M. K. Owens. 1997. Aboveground biomass yields at different densities of honey mesquite. Journal of Range Management 50:550-554

Mannetse, L. T., and K. P. Haydock. 1963. The dry-weight rank method for botanical analysis of pasture. Grass and Forage Science 18:268-275.

McDaniel, K. C., J. H. BRock, and R. H. HaAs. 1982. Changes in vegetation and grazing capacity following honey mesquite control. Journal of Range Management 35:551-557.

Müller, B., K. Frank, and C. Wissel. 2007. Relevance of rest periods in nonequilibrium rangeland systems: a modeling analysis. Agricultural Systems 92:295-317.

Perrings, C., and B. H. Walker. 1997. Biodiversity, resilience and the control of ecological-economic systems: the case of fire-driven rangelands. Ecological Economics 22:73-83.

Pinchak, W. E., W. R. Teague, R. J. Ansley, A. Waggoner, and S. L. Dowhower. 2010. Integrated grazing and prescribed fire restoration strategies in a mesquite savanna: III. Ranch-scale cow-calf production responses. Rangeland Ecology and Management 63:298-307. 
Polley, H. W., H. B. Johnson, and H. S. Mayeux. 1994. Increasing $\mathrm{CO}_{2}$ : comparative responses of $\mathrm{C}_{4}$ grass Schizachyrium and grassland invader Prosopis. Ecology 75:976-988.

Sankaran, M., N. P. Hanan, R. J. Scholes, J. Ratnam, D. J. Augustine, B. S. Cade, J. Gignoux, S. I. Higgins, X. Le Roux, F. Ludwig, J. Ardo, F. Banyikwa, A. Bronn, G. Bucini, K. K. Caylor, M. B. Coughenour, A. Diouf, W. Ekaya, C. J. Feral, E. C. February, P. G. H. Frost, P. Hiernaux., H. Hrabar, K. L. Metzger, H. H. T. Prins, S. Ringrose, W. Sea, J. Tews, J. Worden, and N. Zambatis. 2005. Determinants of woody cover in African savannas. Nature Letters 438:846-849.

[SAS] Statistical Analysis System. 1990. SAS user's guide. Cary, NC, USA: SAS Institute, Inc. 373 p.

Schlesinger, W. H., J. F. Reynolds, G. L. Cunningham, L. F. Huenneke, W. M. Jarrell, R. A. Virginia, AND W. G. Whitford. 1990. Biological feedbacks in global desertification. Science 247:1043-1048.

Scholes, R. J., And S. R. Archer. 1997. Tree-grass interactions in savannas. Annual Review of Ecology and Systematics 28:517-544.

Scifres, C. J., And W. T. Hamilton. 1993. Prescribed burning for brushland management: the south Texas example. College Station, TX, USA: Texas A\&M University Press. 246 p.

Scifres, C. J., W. T. Hamilton, B. H. Koerth, R. C. Flinn, and R. A. Crane. 1988. Bionomics of patterned herbicide application for wildlife habitat enhancement. Journal of Range Management 41:317-321.

Simmons, M. T., S. R. Archer, R. J. Ansley, and W. R. Teague. 2007. Grass effects on tree (Prosopis glandulosa) growth in a temperate savanna. Journal of Arid Environments 69:212-227.

Snyman, H. A. 1998. Dynamics and sustainable utilization of rangeland ecosystems in arid and semi-arid climates of southern Africa. Journal of Arid Environments 39:645-666.

Steel, R. G. D., and J. H. Torrie. 1980. Principles and procedures of statistics. New York, NY, USA: McGraw-Hill. 633 p.

Teague, W. R. 1996. A research framework to achieve sustainable use of rangeland. Agriculture, Ecosystems, and Environment 57:91-102.

Teague, W. R., R. J. Ansley, U. P. Kreuter, W. E. Pinchak, and J. M. McGrann. 2001. Economics of managing mesquite in north Texas: a sensitivity analysis. Journal of Range Management 54:553-560.

Teague, W. R., R. J. Ansley, W. E. Pinchak, S. L. Dowhower, S. A. Gerrard, and J. A. Waggoner. 2008a. Interannual herbaceous biomass response to increasing honey mesquite cover on two soils. Rangeland Ecology and Management 61:496-508.
Teague, W. R., R. Borchardt, R. J. Ansley, W. E. Pinchak, J. Cox, J. K. Foy, and J. M. McGrann. 1997. Sustainable management strategies for mesquite rangeland: the Waggoner Kite project. Rangelands 19:4-8.

Teague, W. R., S. L. Dowhower, and J. A. Waggoner. 2004. Drought and grazing patch dynamics under different grazing management. Journal of Arid Environments 58:97-117.

Teague, W. R., S. E. Duke, J. A. Waggoner, S. L. Dowhower, and S. A. Gerrard. 2008b. Rangeland vegetation and soil response to summer patch fires under continuous grazing. Arid Land Research and Management 22:228-241.

Teague, W. R., W. E. Grant, U. P. Kreuter, H. Diaz-Solis, S. Dube, M. M. Kothmann, W. E. Pinchak, and R. J. Ansley. 2008c. An ecological economic simulation model for assessing fire and grazing management effects on mesquite rangelands in Texas. Ecological Economics 64:612-625.

Teague, W. R., U. P. Kreuter, R. J. Ansley, and J. M. McGrann. 2003. Economics of fire as a follow-up to herbicide treatment of mesquite. In: N. Allsopp, A. R. Palmer, S. J. Milton, K. P. Kirkman, G. I. H. Kerley, C. R. Hurt, and C. J. Brown [eds.]. Rangelands in the new millennium: proceedings of the 7 th International Rangeland Congress; 26 July-1 August 2003; Durban, South Africa. p. 1973-1975.

ThuRow, T. L. 1991. Hydrology and erosion. In: R. K. Heitschmidt and J. W. Stuth [EDS.]. Grazing management: an ecological perspective. Portland, OR, USA: Timber Press. p. 141-159.

uS Department of Agriculture, Soll Conservation Service. 1962. Soil survey of Wilbarger County, Texas. Fort Worth, TX, USA: US Department of Agriculture, Soil Conservation Service. $141 \mathrm{p}$.

Van Auken, 0. W. 2000. Shrub invasions of North American semiarid grasslands. Annual Review of Ecology and Systematics 31:197-215.

WalkeR, B. H. 1987. Determinants of tropical savannas. Oxford, United Kingdom: IRL Press Limited. $156 \mathrm{p}$.

Weltzin, J. F., S. R. Archer, and R. K. Heitschmidt. 1998. Defoliation and woody plant (Prosopis glandulosa) seedling regeneration: potential vs. realized herbivory tolerance. Plant Ecology 138:127-135.

Wilcox, B. P., S. L. Dowhower, W. R. Teague, and T. L. Thurow. 2006. Water balance relationships for honey mesquite rangelands in the Rolling Plains of Texas. Rangeland Ecology and Management 59:600-606.

Wright, H. A. 1974. Effect of fire on southern mixed prairie grasses. Journal of Range Management 27:417-419.

Wright, H. A., and A. W. Balley. 1982. Fire ecology. New York, NY, USA: John Wiley \& Sons. 501 p. 